\title{
CHILDHOOD RISK ESTIMATION OF LEAD METAL POISOINING FROM EDIBLE LAND SNAIL AT ABANDONED BATTERY FACTORY ENVIRONMENT
}

\author{
*Ebenso, I. E. ${ }^{1}$ and Ebenso, G. I. ${ }^{2}$ \\ DOI:http://dx.doi.org/10.4314/ejesm.v4i3.10 \\ Received August $4^{\text {th }} 2011$, accepted October $28^{\text {th }} 2011$
}

\begin{abstract}
The childhood lead $(\mathrm{Pb})$ poisoning risk from consumption and risk model data of snail meat from $\mathrm{Pb}$ metal contaminated sites of entrance (control), storage dump, dried effluent and waste dump at an abandoned battery factory, in Niger Delta, Nigeria were estimated. Results implicated snail meat from waste dump site with hazard quotient of 2.40 and childhood exposure of $0.12 \mathrm{mg} / \mathrm{kg} /$ day $\mathrm{Pb}$ associated with non carcinogenic adverse effects on health. Control site was risk free. Childhood exposure and snail meat $\mathrm{Pb}$ accumulation was dependent on $\mathrm{Pb}$ concentration being significantly higher at non-control sites. This study should fast track industrial environmental audits of existing (including abandoned) industrial projects and epidemiological studies in communities around contaminated/polluted sites.
\end{abstract}

\section{Introduction}

The Environmental Protection Agency has classified inorganic lead $(\mathrm{Pb})$ metal as possible human carcinogen (EPA, 1991). The Pb metal has no nutritional function. In developing countries, $\mathrm{Pb}$ continues to be a significant public health problem (Tong et al., 2000), especially exposure to $\mathrm{Pb}$ from $\mathrm{Pb}$ mining, smelting, battery factory and cottage industries. Environmental exposure to $\mathrm{Pb}$ is a continuing source of mortality and morbidity throughout the world (Adebamowo et al., 2006). About 400 children with mean blood $\mathrm{Pb}$ concentration of $12.00 \mathrm{mg} / \mathrm{L}$ (leads as low as $1.00 \mathrm{mg} / \mathrm{L}$ are associated with impaired neurological development in young children) died of $\mathrm{Pb}$ poisoning, many lived and played around environments of processing of $\mathrm{Pb}$-rich ore for the extraction of gold from local gold mines in Zamfara State, Nigeria in 2010 (Lead 2010). Canfield et al., (2003) reported blood levels of 0.6 $-4 \mathrm{mg} / \mathrm{L}$ during the first years of life of children, and for intellectual performance at pre-school and primary school ages.

Human exposure to $\mathrm{Pb}$ results from various sources, of which food is one of the major routes of exposure in non-occupationally exposed persons (Ebenso and Ologhobo, 2010). In adults, gastrointestinal absorption of $\mathrm{Pb}$ is within the range of 4-11\% (Watson et al., 1986) and may reach 50\% in children ( 0 ' Flaherty, 1995). In addition, it has been shown that $\mathrm{Pb}$ was better absorbed from an empty stomach (Polak et al., 1996). About $99 \%$ of $\mathrm{Pb}$ that enters the adult body and $33 \%$ in children is excreted in 2 weeks after ingestion (ATSDR, 1999). The half-life of elimination (body clearance) is between 2-18 years (Rabinovitz, 1991), with the major route of elimination being faeces. Snails are usually found in large numbers at night at waste dump sites, plantations, covered farmlands and woody debris (Udosen, 2000). Snails are abundant during wet season, when they are easily gathered especially at night and before dawn (Ebenso 2002), by villagers for consumption and sale (Aboua, 1995).

Edible land snails are consumed in Nigeria as a delicacy that supplement low protein diets (Ebenso and Okafor, 2002), such snails are picked (by children) from open and unrestricted environments of wide geographical distribution in diverse terrestrial ecosystems prone to uptake of pollutants. Geographical location of snails could result in patterns of shell shape variation (Ebenso, 2005). Snails might act as sensitive indicator of environmental changes (Ebenso and Ologhobo, 2008a); Ebenso et al., 2010), and can reveal the biologic impact of pollution over geographical and temporal scale (Ebenso and Ologhobo, 2008b). Edible land snails are of interest not only to agriculturists, biogeographers, environmental impact assessors, but also to public health experts and epidemiologists.

The aim of this study was to estimate potential non-carcinogenic risk associated with ingestion of $\mathrm{Pb}$ contaminated edible land snail (Achatina achatina) using consumption and risk model equations for children, a sensitive sub-population, at abandoned battery factory environment, in Niger Delta, Nigeria.

\footnotetext{
${ }^{1}$ Department of Animal Science, University of Uyo, Nigeria

${ }^{2}$ Department of Geography and Regional Planning, University of Uyo, Nigeria

*Corresponding author email: imeebenso@yahoo.com
} 


\section{Methodology}

The study area (Figure 1) was the abandoned Sunshine Batteries Limited (SBL) located at Ukana, in Essien Udim Local Government Area, Akwa Ibom State, Niger Delta, Nigeria, Latitude $5^{\circ} 80^{\prime} \mathrm{N}$ and $7^{\circ} 41^{\prime} \mathrm{E}$. The major raw material for the factory was $\mathrm{Pb}$ metal. This area had an annual precipitation $1300 \mathrm{~mm}$, temperature $26 \pm 2^{\circ} \mathrm{C}$, relative humidity $80-90 \%$ and photoperiod $12 \mathrm{~h}$ light: $12 \mathrm{~h}$ darkness. The experimental sample, edible land snail (Achatina achatina) were from previous study (Ebenso and Ologhobo, 2010), of 4 contaminated soil sites, of entrance (as control), storage dump, dried effluent and waste dump respectively.

Live snails were collected into clean labeled cellophane bags and taken to the laboratory, killed, shocked and weights of shell, foot and offal recorded. A $1 \mathrm{~g}$ tissue sample of snail oven-dried at $60^{\circ} \mathrm{C}$ for 2 days

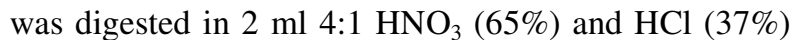
at $140^{\circ} \mathrm{C}$ for $7 \mathrm{~h}$. The sample volume was made up to $10 \mathrm{~mL}$ with distilled water. All digestion procedures included 3-5 control blanks. Atomic Absorption Spectrophotometer (AAS) was used to analyze for $\mathrm{Pb}$ using Perkin Elmer Graphite Furnace AAS 2100.

All data collected from each site for all parameters considered were subjected to analysis of variance using SAS (1999). The means were separated using Duncan Multiple Range Test.

In this study, the estimation (quantification) of non-carcinogenic elevated $\mathrm{Pb}$ risk level to children, were calculated from previous data of Ebenso and Ologhobo, (2010) (Table 1); data from literature (Table 2); data from assumptions in this study (Table 3); using consumption and risk model equations 1 and 2 (EPA, 1989; 2001).

$\begin{array}{ll}\text { Chronic daily consumption of snail }(\mathrm{E}) & =\frac{\mathrm{CF} \times \mathrm{IR} \times \mathrm{FI} \times \mathrm{EF} \times \mathrm{ED}}{\mathrm{BW} \times \mathrm{AT}} \\ \text { Non-cancer hazard quotient (HQ) } & =\frac{\mathrm{E}}{\mathrm{R}}\end{array}$

$$
\begin{aligned}
& \text { Where } \mathrm{E}=\text { Exposure }(\mathrm{mg} / \mathrm{kg} / \text { day }) \text {; } \\
& \mathrm{IR}=\text { Consumption rate }(\mathrm{kg} / \mathrm{meal}) \text {; } \\
& \mathrm{EF}=\text { Exposure frequency (meals/year); } \\
& \mathrm{BW}=\text { Body weight }(\mathrm{kg}) \text {; } \\
& \mathrm{R}=\quad \text { Reference dose of } \mathrm{Pb}(\mathrm{mg} / \mathrm{kg} / \text { day })
\end{aligned}
$$

\section{Results and Discussion}

According to previous study by Ebenso and Ologhobo, (2010) the $\mathrm{Pb}$ accumulated in the snail meat (Table 1) is above the maximum permissible level (MPL) of $1.5 \mathrm{mg} / \mathrm{kg}$ in molluscs, oyster shell and clams as defined in European Commission regulation (EC, 2004).

The Joint FAO/WHO Expert Committee on Food Additives (JECFA), (WHO, 2000) has established a provisional tolerable weekly intake (PTWI) for $\mathrm{Pb}$ of $0.25 \mathrm{mg} / \mathrm{kg}$ body weight $/$ week (equivalent to $0.04 \mathrm{mg} / \mathrm{kg}$ body weight/day) for children. On the basis that $\mathrm{Pb}$ is accumulating in the body and an increase of the body burden of $\mathrm{Pb}$

\author{
$\mathrm{CF}=\mathrm{Pb}$ concentration in snail $(\mathrm{mg} / \mathrm{kg})$ \\ $\mathrm{FI}=$ Fraction consumed from $\mathrm{Pb}$ \\ $\mathrm{ED}=$ Exposure duration (years) \\ $\mathrm{AT}=$ Averaging time (days);
}

should be avoided (WHO, 2000). In Table 4, children were at risk of consuming snails from the waste dump site having value of $0.12 \mathrm{mg} / \mathrm{kg}$ body weight/day, with an associated increasing body $\mathrm{Pb}$ burden.

With EPA's non-cancer toxic elevated effect risk level, the level at which there is no increased risk of toxic effect, is a hazard quotient (HQ) of 1. The risk of snails from waste dump site was $H Q>1$. At this high HQ of 2.40, it indicates cardiovascular, reproductive, developmental and immunological effects, as well as blood and metabolic disorders and effects on general brain function (EPA, 1991). Data by Tong et al., (1998), showed that even when such children stopped ingesting $\mathrm{Pb}$ from snail, after first exposure, such effects are largely irreversible. 
Accumulated epidemiological evidence indicates that such exposure in early childhood causes a discernible deficit in cognitive development during the immediately ensuing childhood years (Tong, 1998).

It is important to note that, the measure of effect for $\mathrm{Pb}$ is the reference dose $(\mathrm{R})$. This is defined as an estimate of a daily exposure to $\mathrm{Pb}$ in humans (EPA, 2001) including sensitive sub-population like children, which is the main target of this study. Once $\mathrm{R}$ is exceeded (as in the case of children at non-control sites, Table 4), a child is at increased risk of adverse health effects.

The Human Health Focus Group (EPA, 2001) reported that children who eat more than $0.18 \mathrm{~kg} / \mathrm{meal}$ of shell fish are at risk of an additional chance of developing adverse health conditions, due to increasing $\mathrm{Pb}$ toxicity, not diluted.

In risk assessment, the inclusion of the toxicity of chemical(s) and the exposure assessment helps to determine the level of risk. Therefore, in this study the acceptable level of risk (beyond which adverse health effects are clinically noticed) for children who consumed $\mathrm{Pb}$ contaminated snails from abandoned factory environments is $0.05 \mathrm{mg} / \mathrm{kg}$, this is also the $\mathrm{R}$ for $\mathrm{Pb}$ (Krasovskii et al., 1979; Rice and Karpinski, 1988). Childhood $\mathrm{Pb}$ poisoning will occur when children consume snails from non-contaminated sites (see Table 4), above $0.04 \mathrm{mg} / \mathrm{kg}$ bodyweight/day (PTWI for $\mathrm{Pb}$ ).

Even though at HQ of 2.40, the snail from sites except the waste dump sites may be considered safe for consumption, however, the PTWI for $\mathrm{Pb}$ and the $\mathrm{R}$ data implicated snails from all the non-control sites, and hence childhood risk is at elevated levels due to $\mathrm{Pb}$ toxicity, supported by $\mathrm{R}$ data. According to Canfield et al., (2003), detectable deficits may occur even at exposure levels previously considered to be safe. Due to their smaller body weights, children with a high consumption of food with high $\mathrm{Pb}$ levels are at a greater risk to exceed the PTWI for $\mathrm{Pb}$ than adults (Opinion on Lead, 2004).

Observed contaminations in food chain at abandoned should kick-start industrial environmental audits and epidemiology studies (Ukpong, 2009). This environmental problem calls for urgent intervention (Udofia, 2010).

\section{Conclusion}

This study is the first attempt of use of snail biodiversity to estimate non-cancer risk of adverse childhood $\mathrm{Pb}$ poisoning from contaminated sites. Data were limited by absence of Nigerian national population census data of 2006 on children around the factory environment. This study goes a long way to show that lack of incorporation of uptake and bioavailability data of metal in food chain does not give a true picture of impacts of hazardous chemicals in communities, as only chemical data in soil and water are usually considered in environmental impact assessment (EIA).

\section{References}

Aboua, F. (1995). Proximate analysis and mineral content of two giant African snails consumed in Ivory Coast. Tropical Science 35:220-222.

Adebamowo, E. O., Ayede, O. A., Sridhar, M. K. C. and Adebamowo, C. A. (2006). An examination of knowledge, attitudes and practices related to lead exposure in South-western Nigeria. BMC Public Health 6(1):82-84.

ATSDR (Agency for Toxic Substance and Disease Registry) (1999). Toxicology profile for lead. Report 205-93-0606. Department of Health and Human Services. Public Health Service, Atlanta.

Canfield, R. L., Henderson, C. R. jr, Cory-Slechta, D.A., Cox, C., Jusko, T. A. and Lanphear, B. P. (2003). Intellectual impairment in children with blood heart concentration below 10 microgram per deciliter. New England Journal of Medicine 348:1517-1526.

Ebenso, I. E. (2002). Consumption and sales of domesticated snails Archachatina marginata in rural Southern Nigeria. Tropical Science 42:182-187.

Ebenso, I. E. (2005). Morphometric variation in shell shape of Achatina achatina. Nigeria Journal of Agriculture, Food and Environment 2(1):65-69.

Ebenso, I. E. and Okafor, N. M. (2002). Alternative diets for growing Archachatina marginata in South eastern Nigeria. Tropical Science 42(3):144-145.

Ebenso, I. E. and Ologhobo, A. D. (2008 a). Edible land snail shell thickness as bioindicator of environmental lead metal pollution. Pollution Research 27(2):75-76.

Ebenso, I. E. and Ologhobo, A. D. (2008 b). Effects of lead pollution from vehicular exhaust fumes against sentinel juvenile Achatina achatina. Bulletin 
of Environmental Contamination and Toxicology 81:513-515.

Ebenso, I. E. and Ologhobo, A. D. (2010). Evaluation of environmental lead exposure in snails from four contaminated sites at abandoned battery factory in Niger Delta, Nigeria. Nigeria Journal of Animal Production 37(2):258-263.

Ebenso, I. E., Ologhobo, A. D. and Udotong, I. R. (2010). Edible land snail biodiversity as indicator in environmental impact assessment (EIA) studies. Proceedings of $15^{\text {th }}$ annual conference of Animal Science Association of Nigeria, Uyo pp239-240.

EC (European Commission) (2004). Assessment of the dietary exposure of arsenic, cadmium, lead and mercury of the population of all member states. Scientific Committee on Animal Nutrition. European Commission, Brussels.

EPA (Environmental Protection Agency) (1989). Risk assessment guidance for superfund volume I. Human health evaluation manual (Part A). Report EPA/540/1-89/002. Office of emergency and remedial response. EPA, Washington.

EPA (Environmental Protection Agency) (1991). Integrated risk information system - lead and compounds (inorganic). Report 7439-92-1 EPA, Washington.

EPA (Environmental Protection Agency) (1997). Exposure factors handbook. EPA, Washington.

EPA (Environmental Protection Agency)(2001). Exposure potential model. National exposure research laboratory, Washington.

Krasovskii, G. N., Vasukovich, L. Y. and Charie, O. G. (1979). Environmental study of biological effects of lead and aluminium following oral administration. Environmental Health Perspective 30:47-51.

Lead (2010). Lead poisoning kills children in Zamfara State, Nigeria. <www.msf.com>.

O'Flaherty, E. J. (1995). Physiologically-based models for bone-seeking elements: Lead absorption and disposition in childhood. Toxicology and Applied Pharmacology 138:121-130.

Opinion on Lead (2004). Opinion of the Scientific Panel on Contaminants in the Food Chain, European Union. EFSA Journal 71:1-20.

Polak, J., O'Flaherty, E. J., Freeman, J. D., Johnson, J. D., Liao, S. C. and Bergstorm, P. D. (1996).
Evaluating lead bioavailability data by means of a physiologically based lead kinetic model. Fundamentals of Applied Toxicology 29:63-70.

Rabinovitz, M. B. (1991). Toxicoknietics of bone lead. Environmental Health Perspective 91:31-37.

Rice, D. C. and Karpinski, K. (1988). Lifetime lowlevel lead exposure produces deficits in delayed alteration in adult monkeys. Neurotoxicology 10:207-214.

SAS (Statistical Analysis Systems) (1999). Users guide statistics, Version 9. SAS Institute, New Carolina.

Tong, S. (1998). Lead exposure and cognitive development: persistence and a dynamic pattern. Journal of Paediatrics and Child Health 34:114-118.

Tong, S., Mc Micheal, A. J. and Prapamontol, T. (1998). Declining blood lead levels and changes in cognitive function during childhood. Journal of the American Medical Association 280:1915-1919.

Tong, S., Von Schivnding, Y. E. and Prapamontol, T. (2000). Environmental lead exposure: a public health problem of global dimensions. Bulletin of the World Health Organization 78(9):1068-1077.

Udofia, E. P. (2010). Environmental Problems. In: Akwa Ibom State a geographical perspective, Usoro, E. J. and Akpan, P. A. (eds.). Department of Geography and Regional Planning, University of Uyo/Immaculate Publishers, Enugu.

Udosen, C. E. (2008). Rainfall analysis and forecasting in Akwa Ibom State. Uwana Graphics, Uyo.

Udosen, E. D. (2000). Levels of toxic metals in Achatina achatina from parts of Akwa Ibom State, Nigeria. Journal of Environmental Sciences 12:6874.

Ukpong, I. E. (ed.) (2009). Perspectives on environmental management. Environmental Systems Club Inc., Uyo.

Watson, W. S., Morrison, J., Baldwin, N. M., Lyon, D. T. B., Dobson, H., Moore, M. R. and Hume, R. (1986). Food iron and lead absorption in humans. American Journal of Clinical Nutrition 44:248-256.

WHO (World Health Organization) (2000). Lead. In: Safety, evaluation of certain food additives and contaminants. Joint FAO/WHO Expert Committee on Food Additives. WHO, Geneva 
Table 1 Lead contaminated snail (Achatina achatina) meat from battery factory sites

\begin{tabular}{|c|c|c|c|c|c|}
\hline PARAMETER & CONTROL & STORAGE DUMP & DRIED EFFLUENT & WASTE DUMP & SEM \\
\hline \multicolumn{6}{|l|}{ Carcass anatysis } \\
\hline Foot weight $g$ & $37.23 \mathrm{a}$ & $36.46 b$ & $35.63 \mathrm{c}$ & $32.46 \mathrm{~d}$ & 0.01 \\
\hline Shell weight $g$ & $24.34 \mathrm{a}$ & $22.93 b$ & $21.34 \mathrm{c}$ & $19.47 d$ & 0.01 \\
\hline Dressing \% & $46.37 \mathrm{a}$ & $45.45 b$ & $45.06 \mathrm{c}$ & $44.63 d$ & 0.01 \\
\hline Shell weight/Live weight $\%$ & $28.04 \mathrm{a}$ & $28.52 \mathrm{a}$ & $26.72 b$ & $26.99 b$ & 0.01 \\
\hline \multicolumn{6}{|c|}{ Lead accumulation in snail meat } \\
\hline $\mathrm{Pb} \mathrm{mg/kg}$ & $1.76 \mathrm{~d}$ & $12.20 \mathrm{c}$ & $91.38 \mathrm{~b}$ & $468.50 \mathrm{a}$ & 0.13 \\
\hline
\end{tabular}

abc.. means followed by different letters are significantly different $\alpha=0.05$

Source: Ebenso and Ologhobo (2010).

Table 2 Data from literature used for childhood non-carcinagenic risk estimation

\begin{tabular}{llr}
\hline ABBREVIATION* & DATA & AUTHOR \\
\hline BW & & EPA, (2001) \\
IR & $20.00 \mathrm{~kg}($ children $\leq 7$ years $)$ & EPA, (2001) \\
R & $0.18 \mathrm{Kg} / \mathrm{meal}($ Shellfish) & Krasovskii et al., (1979) \\
FI & $0.05 \mathrm{mg} / \mathrm{kg} \mathrm{Pb}$ day & EPA, (1997) \\
CF & 0.40 & Ebenso and Ologhobo, (2010)
\end{tabular}

* See equations 1 and 2

** See Lead accumulation in snail meat (Table 1)

TABLE 3 Data from assumptions by present authors in childhood non carcinogenic risk estimation

\begin{tabular}{|c|c|c|c|c|}
\hline ABBREVIATION* & DATA & \multicolumn{3}{|c|}{ ASSUMPTION } \\
\hline ED & 20 years & \multicolumn{3}{|c|}{ Period since abandonment of SBL factory till date } \\
\hline $\mathrm{EF}$ & 26 meals/year & \multicolumn{3}{|c|}{26 weeks ( 6 months of rainy season**), with snail in a meal/week } \\
\hline \multicolumn{5}{|c|}{$\begin{array}{l}* \text { See equations } 1 \text { and } 2 \\
* * \text { Udosen, }(2008)\end{array}$} \\
\hline PARAMETER & CONTROL & STORAGE DUMP & DRIED EFFLUENT & WASTE DUMP \\
\hline \multicolumn{5}{|l|}{ Measured } \\
\hline $\begin{array}{l}\mathrm{Pb} \text { concentration in snail } \\
\text { meat }(\mathrm{mg} / \mathrm{kg})^{*}\end{array}$ & 1.76 & 12.20 & 71.38 & 468.50 \\
\hline \multicolumn{5}{|l|}{ Modeled } \\
\hline $\mathrm{E} \quad(\mathrm{mg} / \mathrm{kg} / \mathrm{day})$ & 0.001 & 0.01 & 0.02 & 0.12 \\
\hline HQ & 0.02 & 0.20 & 0.46 & 2.40 \\
\hline
\end{tabular}

* See Table 1 


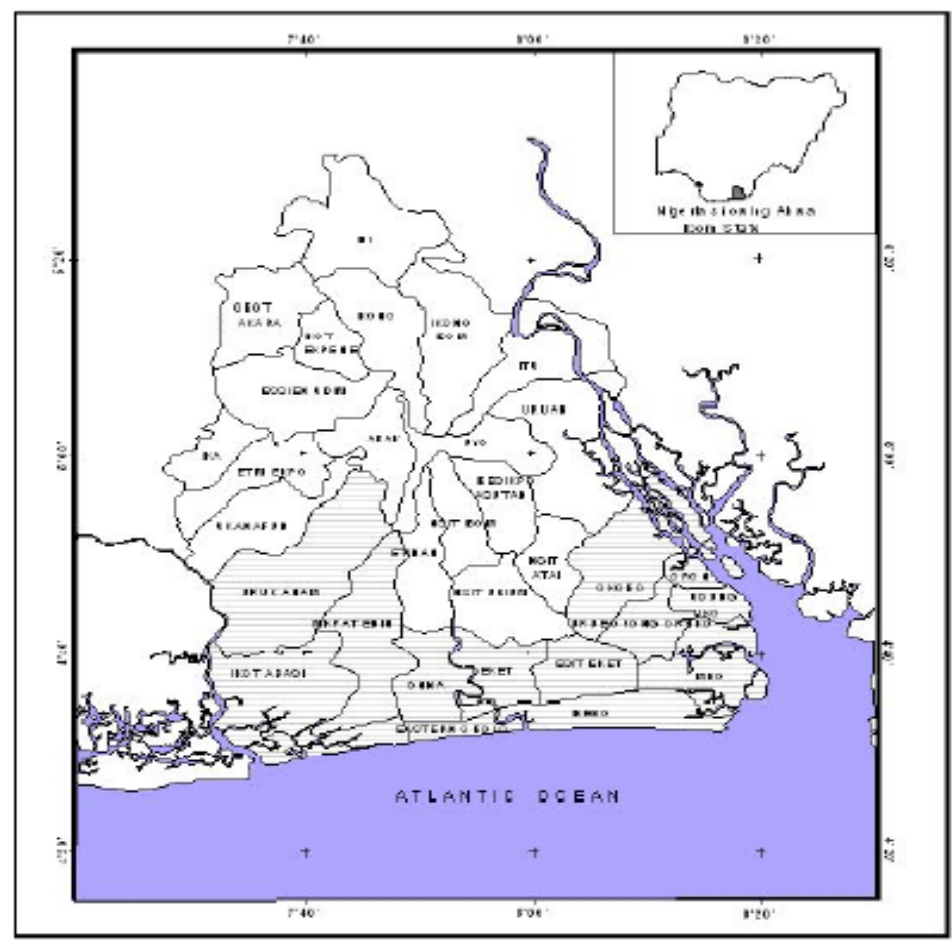

Figure 1: Study Area 